\title{
RNAi Mediated Drought and Salinity Stress Tolerance in Plants
}

\author{
Akash Pradhan, Nupur Naik, Khirod Kumar Sahoo* \\ Department of Botany, Ravenshaw University, Cuttack, India \\ Email: ${ }^{*}$ khirod555@gmail.com
}

Received 25 June 2015; accepted 22 August 2015; published 25 August 2015

Copyright (C) 2015 by authors and Scientific Research Publishing Inc.

This work is licensed under the Creative Commons Attribution International License (CC BY). http://creativecommons.org/licenses/by/4.0/

(c) $\underset{\mathrm{EY}}{\mathrm{O}}$ Open Access

\section{Abstract}

RNAi mediated gene silencing demonstrated to serve as a defence mechanism against abiotic stress. Some endogenous small RNAs (microRNA and siRNA) have emerged as important players in plant abiotic stress response. Drought and salinity are the major environmental stresses that limit the agricultural food production. miRNA involved in drought and salinity stress response, including ABA response, auxin signalling, osmoprotection and antioxidant defence by downregulating the response target gene. It is observed that some of the microRNAs are upregulated or downregulated in response to drought and salt stress. We reviewed that miR167, miR393, mir474, miR169g are upregulated whereas miR168, miR396, miR397 are downregulated in rice plant during drought stress. Moreover, our detail categorical analysis on the basis of mechanism of action found that miRNA involved in drought stress was $28 \%$ in ABA signalling and response, $14.2 \%$ in auxin signalling, $9.52 \%$ in miRNA processing, $14.2 \%$ in cell growth, $9.52 \%$ in antioxidant defence, $4.76 \%$ in $\mathrm{CO}_{2}$ fixation and $9.52 \%$ in osmotic adjustment. Similarly, miRNA involved in salinity stress was $5.8 \%$ in auxin signalling, $23.5 \%$ in vegetative phase change and root, shoot, leaf and vascular development, $11.76 \%$ in gynoecium and stamens development, $8.82 \%$ in metabolic adaptation, $2.74 \%$ in early embryogenesis and $41.17 \%$ not known. Importantly, some common miRNAs such as miR159, miR167, miR169, miR393 and miR397 play an important role in both drought and salinity stress conditions. Here, in this review, we mainly focused on the current status of miRNAs, mechanism of action and their regulatory network during drought and salinity stress in plants.

\section{Keywords}

RNAi, miRNA, siRNA, Drought Stress, Salinity Stress, Rice Plant, Gene Regulation

\footnotetext{
${ }^{*}$ Corresponding author.
} 


\section{Introduction}

Agriculture productivity is negatively affected due to various abiotic factors. It is well understood that crops tolerating environmental stresses will be in high demand, as the world is getting hotter and drier day by day [1]. The uneven rainfall and decrease of ground water level often create drought stress conditions in the environment, which in term affect the total grain yield of plants. The reasons for reduction of sustainable production include global climate change, less availability of arable land and water and increasing rate of world population [2]. Unfavourable environmental factors lead to tremendous loss in productivity globally. Among the various environmental abiotic factors, drought and salinity stresses cause huge loss than any other abiotic stress. Drought and salinity stress tolerance and adaptation in rice plants have been improved by engineering various transcription factors, genes related to signalling pathway, compatible solutes and accumulation of antioxidants. The importance of many genes related to several pathways has been clearly elucidated in a review of stress tolerance mechanisms and use of transgenic technology in agriculture for developing abiotic stress tolerant crop plants [3]. Besides this, recently a review reported on structure, function and networks of the transcription factors involved in abiotic stress responses [4]. So, it is very essential to evaluate the exact role of specific transcription factor(s) or gene(s) and then genetic manipulation for the crop improvement. Now, many researchers are trying to improve the rice plants by using transcriptomics, proteomics and metabolomics approaches to identify and characterize various genes involved in drought and salinity stress responses. Therefore, it is important and essential to evaluate the exact role of specific small RNA followed by genetic manipulation for the crop improvement.

The small non-coding endogenous RNAs (18 - 24 nucleotides) which regulate gene expression at posttranscriptional level by sequence specific mRNA degradation in plants are known as microRNAs (miRNAs). RNA interference (RNAi) indicates that it suppresses the gene expression by degrading the specific messenger RNAs (mRNA) [5]. The RNA process is triggered by the introduction of double stranded RNA (dsRNA) via transgene which is further cleaved by the enzyme dicer to form duplex of 21-nucleotide [6]. The duplex 21-nucleotide is the form, commonly called as small interfering RNA (siRNA), which is responsible for degradation of mRNA, thus leading to suppression or alteration of the gene expression [5]. RNAi mechanism has the potential in identification and functional assessment of thousand of genes within any genome which can be responsible for crop improvement [7]. The RNAi technology has been employed successfully in improvement of several plant species by increasing their nutritional value, resistance against pathogen [8] [9] and tolerance to abiotic stress [10].

So far, RNAi technology has been evolved as one of the promising approach used to engineer several metabolic processes of plants for different nutritional improvements, such as lysine reduction in maize [11] [12], glutenin reduction in rice [13], increasing amylose content in wheat [14] and potato [15], improving carotenoid and flavonoid in levels of tomato fruits [16], carotenoid content of rapeseed [17], reduction of caffeine content in coffee [18], and reduction of phytate content in soybean [19] and in rice [20]. Recently, RNAi emerges as a powerful and more determinant technology to study the gene loss of a function phenotype which leads to gene functional analysis when no mutant alleles are unavailable. This review focused on the landmark in RNAi discovery, its component and mechanism of action and its role in abiotic stress tolerance in plants, basically drought and salt stress tolerance.

\section{Discovery of RNAi in Plants}

The discovery of RNAi was an accidental and surprising observation found in Petunia. In 1990 when the Jorgensen et al. introduced exogenous transgene in Petunias in an attempt to up regulate the activity of a gene for chalcone synthase (an enzyme involve in production of specific pigment) under the control of 35 s promoters [10]. Unexpectedly, the flower pigmentation was not appeared deep purple colour, but rather showed variegations with complete loss of colour in some cases. This implies that not only the introduced transgene were inactive but that the added DNA also affected the expression of endogenous loci. The phenomenon was referred to as co-suppression. Later, Guo and Kemphus (1995) while investigating the function of par1 gene in the Nematode $C$. elegans, they found that when introducing either sense or antisense RNA for the par1 gene resulted its suppression [21]. Further, Andrew fire and Craig Mello (1998) observed that the injection of double stranded RNA mixture that is both sense and antisense strands are more efficient for silencing the target gene than either of the strand alone [22]. This turned out to be the defining moment in RNAi research and the effect known as RNA interference [10]. Earlier, the brief molecular mechanism of RNA interference responsible for gene silencing has been reported [6]. 


\section{Component of RNAi}

Out of the component of gene silencing, some serve as initiator and other serve as effectors, amplifiers and transmitters. Dicer which was first discovered by Bernstein et al. (2001) in Drosophilla, is a complex ribonuclease enzyme belonging to the RNase III family [23]. It has four different domains, each with a very specific function and they are having N-terminal helicase, dual RNase III motifs, C-terminal double stranded RNA binding domain and PAZ (piwi/argonaute/zwille) domain [5] [24]. The role of dual RNase III motifs is to perform the actual cutting of the double stranded RNA, hence, the characteristics 5' phosphate and 3' hydroxyl residues of siRNA are formed [5]. Double stranded RNA continuously cleaved by dicer at 21 to 25 base pair distance. Dicer works in first step of RNAi pathway and act as a catalyst which helps in starting production of RNA induced silencing complex (RISC). Agronaute, a catalytic component of dicer, has the potential to degrade mRNA complementary to that of siRNA guide strand [6]. RISC is a major component of the RNAi machinery that uses the siRNA to target and degrade the mRNA in the cell and complementary to the siRNA strand. So, RISC consists of both protein and RNA [5]. When RISC finds mRNA complementary to siRNA, it activates RNAase enzyme resulting the cleavage of target RNA. About 20 to $23 \mathrm{bp}$ siRNA are able to associate with the RISC and guide the complex to the target mRNA and combine together and degrade them as a result reduced level of protein translation and knockdown the gene function [6]. RISC acts as catalyst to cleave single phosphodiester bond of mRNA [25].

\section{Mechanism of Post Transcriptional Gene Silencing through RNAi Pathway}

There are two small RNA in the RNAi pathway, a small interfering RNA (siRNA) and a micro RNA (miRNA). miRNA are similar to siRNA in many respect as they originate from double stranded structure, the size of the miRNA is 20 to $30 \mathrm{bp}$ and both are proceed by DICER or DICER like enzyme (DCL1, DCL2). RISC uses as both target sequence and they direct post transcriptional gene silencing. They differ from each other in their origin. miRNA is derived from genomic DNA, while siRNA is generated by chopping of dsRNA into smaller segment. Active miRNA has two phases that is primary miRNA (pri-RNA) and pre-miRNA. Both pri and premiRNA are characterized by a hair pin structure. Processing of miRNA occurs of both at the nuclear and cytoplasmic levels [5]. Once a miRNA gene is transcribed, the transcript will form a roughly 42 to 60 bp long hairpin structure with two arms of approximately the same length. Out of these, one of the strands produces active miRNA via DICER.

RNA interference pathway majorly follows four common steps such as i) dsRNA cleaved by dicer; ii) entry of SiRNA into RISC complex; iii) silencing complex activation; iv) mRNA degradation [10]. In the first step of RNAi, the introduced dsRNA in the cell, which is perfectly homologous in sequence to the target gene, is recognise by DICER enzyme (Figure 1).

Dicer enzyme further processes the dsRNA in an ATP dependant reaction into dsSiRNA of 21 - 25 nucleotides. Then, the SiRNA produced by the dicer are incorporated into multicomponent nucleus complex into the RNA induced silencing complex, which is inactive in this form to conduct RNAi. The next step involves unwinding of the SiRNA duplex in an ATP dependent process by a helicase and further remodelling of the complex to create an active form of the RISC [26]. Initially, it was believed that the unwinding of the DNA strand caused by the ATP dependent helicase but the process is actually ATP independent and performed directly by the protein component of the RISC. RISC is a ribonucleoprotein complex and its two important components are the single stranded SiRNA and the agronaute family protein [6]. The next step is degradation of mRNA. The active component of an RISC are endonuclease called agronaute protein which cleave the target mRNA strand complementary to their bound SiRNA, therefore agronaute contribute "silencer" activity to RISC. When the dsRNA chopped by the dicer produced the small SiRNA, in which one strand is known as guide strand binds that the agronaute protein and directs gene silencing. After the cleavage is complete, the RISC departs and the SiRNA can be reused in a new cycle of mRNA recognition and cleavage (Figure 1 ).

One interesting feature encountered in the RNAi is its apparent catalytic nature. Through the cleavage of dsRNA into small SiRNA by dicer result in some degree of amplification, it is not sufficient to bring about continuous mRNA degradation [27] [28]. It provides very convincing genetic and biochemical evidence that RNA dependent RNA polymerase play a vital role in increasing the RNAi effect. The enzyme RdRp (RNA dependent 


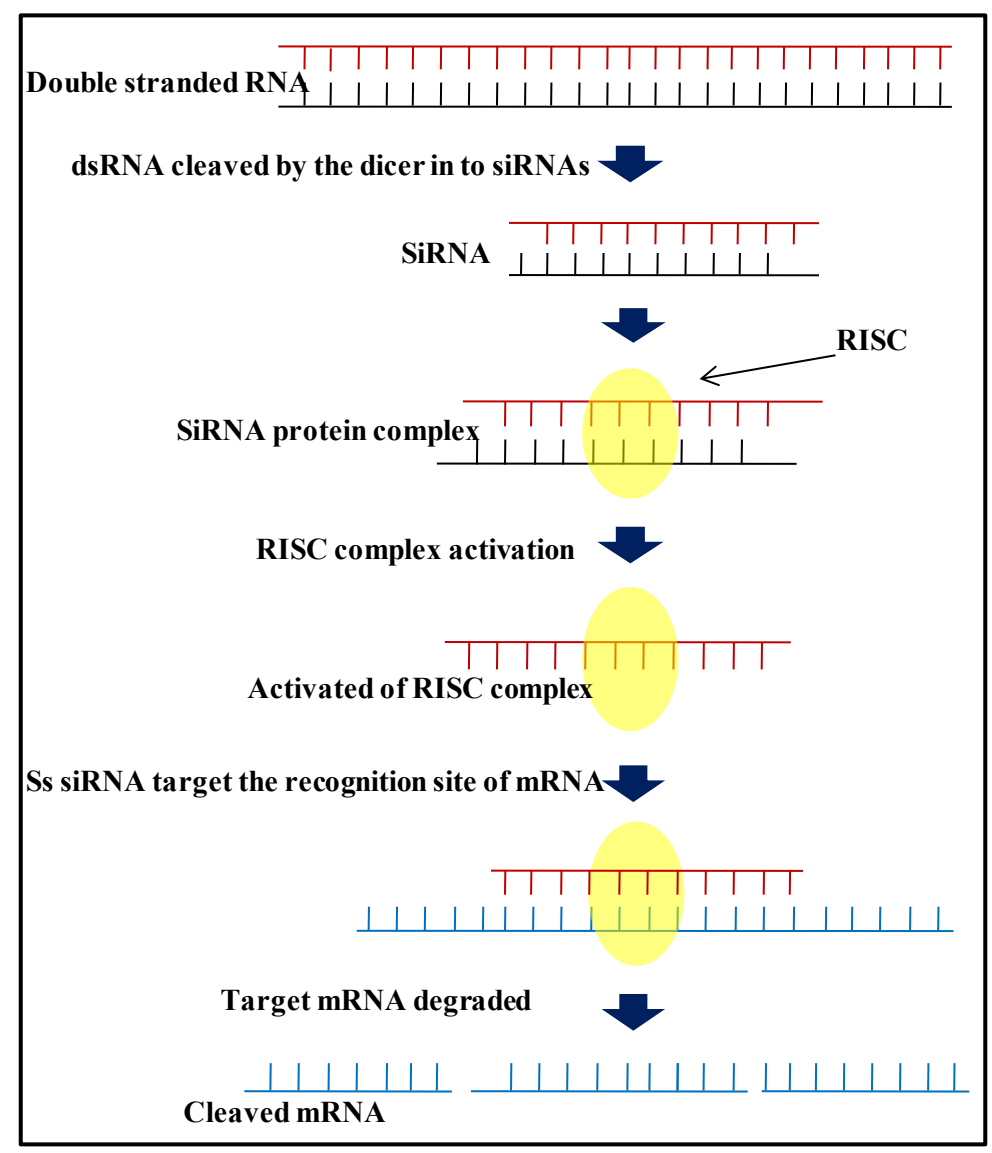

Figure 1. Schematic diagram shows the mechanism of post transcriptional gene silencing through RNAi Pathway.

RNA polymerase) uses SiRNAs as primers to generate new dsRNA that can be further cleaved into new SiRNA [29]. So, RNAi technology is coming out as a convincing approach in which short dsRNA suppress the expression of specific gene by inducing the homologous sequence of the target mRNA in the cytoplasm.

\section{Role of RNAi in Abiotic Stress}

Stress is usually defined as an external factor that exerts a disadvantageous effect or harmful effect on the plant. Abiotic stress causes the serious damages for the life on the earth particularly to the plant by negatively affecting its growth and yield. It has been estimated that nearly $70 \%$ of crop yield is reduced due to the abiotic stress [7]. Plants are subjected to many types of fluctuations in the physical environment. In general, various types of strategies have been used to avoid the fluctuation by the animals but plants are not able to avoid because of their sessile nature. Therefore, plants have adapted numerous physiological, biochemical and metabolic approaches for tolerating the abiotic stress. Abiotic stress are classified into the following major categories such as drought, salinity, heat, cold and oxidative stress. Classical techniques of breeding crop plants with enhance tolerance to abiotic stress have until now achieved inadequate success. Therefore, transgenic technology is one of the numerous tools offered improvement in modern plant breeding programme. Identification of candidate gene through functional genomics programmes discovered multiple gene families which regulates the abiotic stress tolerance phenomena and high production. Therefore, researchers are trying to incorporate the candidate gene or multiple numbers of genes to express ectopically for crop improvements [7].

Now days, RNAi technology has been evolved a modern approach for gene function analysis and in translational research programme. Recent findings manifest the RNAi is playing an important role in abiotic stress stimulation in different crops. RNAi technology may be a substitute of complex molecular techniques because of containing several benefits, its specificity and sequence based gene silencing. Due to this property, RNAi has 
been effectively utilized for incorporating desired trait for abiotic stress tolerance in various plant species [30]. Micro RNAs has an important gene expression regulator during plant abiotic stress [31]. Micro RNA biogenesis and its mechanism of action have already been discussed earlier. miRNA under specific conditions can regulate the expression of specific target gene.

In abiotic stress condition, the plant after signal perception, the abiotic stress responsible miRNA gene undergoes transcription by RNA Polymerase II enzyme into primary miRNA (pri-miRNA), the miRNA is proceed by dicer like DCL 1 into a stem loop miRNA duplex. The 3' ends of the miRNA duplex are methylated by HEN1 (Figure 2). The miRNA is then exported into the cytoplasm from the nucleus by the HASTY protein and cleave into mature miRNAs. The mature miRNAs are incorporated into RNA induced silencing complex (RISC), where the mature single stranded miRNA guides the RNA silencing activity of AGO1 to partially complementary mRNA. The microRNA then targets the abiotic stress responsive mRNA and that causes translation repression and mRNA degradation [32].

\section{Drought Stress Response}

Drought is one of the harmful abiotic stress factors that render the plant growth and development. Plant respond and adapt to drought stress through various physiological and metabolic processes including stomatal closure, repression cell growth, photosynthesis and activation of respiration to increase the chance of survival [33]. The molecular mechanism drought stress tolerance is extremely complicated which is a multigene phenomenon in Arabidopsis plants [34]. Signal transduction in response of drought stress can be divided in to two pathway, $\mathrm{ABA}$ independent and $\mathrm{ABA}$ dependent pathway [35]. It was observed that transcription factor belonging to class of MYC and MYB superfamily, ABA binding factor (ABF), Zinc finger protein (ZFP), ethylene responsive factors (ERF), NAC, basic leucine zipper (bZIP) play key role in regulating expression of candidate genes in both the pathways [35] [36]. However, the DRE-binding protein DREB1F functions as molecular bridge between ABA independent and dependent response [35]. The role of ABA in plant growth and development and its main function is to regulate water balance in plant and osmotic stress tolerance. Thus, ABA accumulation is considered as a supreme mechanism in response to drought stress, which cause stomatal closure and induced drought related genes and that ultimately enhance the plant stress response [37].

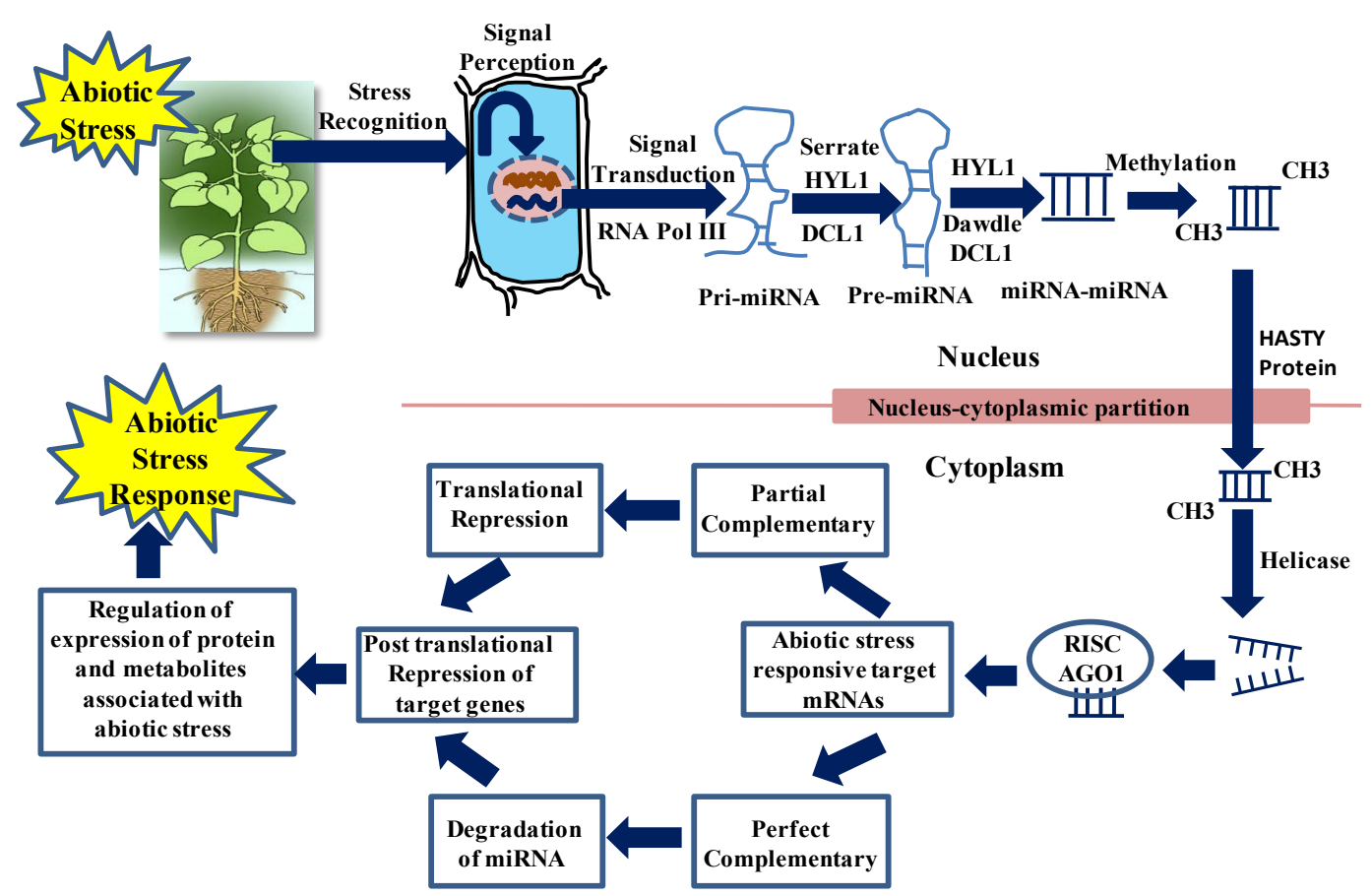

Figure 2. Pathway showing the steps involves in post transcriptional regulation mediated by abiotic stress responsive miRNA genes in plants. (DCL1-Dicer like Protein 1, HYL1-Hyponastic Leaves1, Pri-mRNAPrimary mRNA, RISC-RNA Induced Silencing Complex, AGO1-Argonaute1). 


\section{Expression of Micro RNAs during Drought Stress}

Now days, miRNAs have been emerged as key modulator in drought avoidance and also in drought tolerance by controlling of the drought responsive gene(s). It has been reported that drought induced miRNAs downregulate their target mRNA, which results in production of nonfunctional protein in drought stress response. In contrast, the downregulation of few miRNA lead to accumulation of their target mRNA which have positive effect to stress adaptation [32]. The miRNA expression profiling has been done in many plants such as Arabidopsis, populus trichocarpa, Oryza sayiva under drought stress. The miR169, miR 396, miR171, miR319, miR393, miR156, miR158 known to be drought responsive [7] [38]. The role of miRNA (miR159) was found to be induced by ABA and drought treatment in germinating Arabidopsis seeds [39]. In Arabidopsis, miR159 mediates the cleavage of MYB101 and MYB33 transcripts [39]-[41]. Its role in ABA signalling and their mechanism are evaluated by overexpresing miR159 which suppressed MYB101 and MYB33 mRNA level. So, the transgenic plant over expressing of MYB101 and MYB33 were hypersensitive to ABA [32] [39] and improved osmotic stress tolerance. MYB functions as a positive regulator of ABA signalling and miR159 which probably play a key role in ABA response in Arabidopsis plant [32]. Interestingly, it has been reported that miR167 was downregulated by treatment of $\mathrm{ABA}$ in rice seeding [42], in contrast, its expression was upregulated by drought stress in Arabidopsis [38].

\section{Regulation of Drought Stressed Target Gene Associated miRNAs}

Phospholipase D (PLD) was found to be a positive regulator of drought stress resistance and was proposed as a target of miR167. In drought stress, the expression of miR167 was inhibited in maize (Zea mays), which was essential for the accumulation of PLD mRNA [32] [43]. PLD was reported to direct ABA response and affect stomatal movement in guard cells [44] [32]. Thus, it indicated that miR167 mediated PLD activation is important in the process of ABA signalling or response [32]. miR 169 targets the NFYA5 mRNA, encoding a subunit of the nuclear factor Y (NF-Y) transcription factor [45]. NF-Y proteins are plant specific transcription factor and play key role in environment stress response and plant development. miR169 was downregulated by drought stress and ABA treatment in Arabidopsis and the down regulation of miR169 helps the strong induction of NFYAS transcription factor. Over expression of NFYA5 lead to drought tolerant phenotypes whereas over expression of miR169 are very sensitive to drought stress [32]. Auxin response factors (ARFs) are major transcription factor (TF) involving Auxin signalling. There are several ARFs family are targeted by miRNAs, out of which ARF16 and ARF17 are targeted by miR160. It has been reported that ABA, helps in accumulation of the ARF mRNA by downregulated the miR160 [42] in rice seedling. It has been also been found that in Arabidopsis during germination, transgenic seed over expressing miR160 exhibited ABA insensitive or tolerant during germination while transgenic plant expressing the miR160 resistance form of ARF10 exhibited ABA hypersensitive phenotype during germination [46]. From this, it was observed that down regulated of ARF10 by miR160 affect the ABA sensitivity. Thus miR160 play a key role in ABA response and drought stress.

In Arabidopsis and rice, miR393 were upregulated and it target the TIR1 (transport inhibitor response 1), an auxin receptor play an important role in auxin signalling [47]. Over expressing the miR393 in rice seedling suppress the growth of the plant in drought stress [48]. This indicates that over expression miR393; down regulate the auxin signalling which may reduce the growth of the plant during drought stress. miR396 was found to upregulate in Arabidopsis [38] and tobacco but down regulated in rice during drought stress [49]. miR396 target the six GRFs (growth regulating factors) with role in cell division and differentiation during leaf development [50]. It has been observed that transgenic Arabidopsis plant over expressing miR396 showed narrow leaf phenotypes because of reduction in cell number due to suppression of GRF genes [51] and cell cycle related gene that is CYCD 3:1, histone H4, CYCA 2:1 and CYCB 1:1 [52]. Transgenic tobacco plant over expressing the miR396 improves drought stress tolerance by lowering the stomata density observed [51] [53]. In plant, miR396 not only play a role in leaf development but also tolerance to drought stress.

miR166 was upregulated in Medicago truncatula [54] and were downregulated in Oryza sativa and Triticum dicoccoides [55] in drought stress. It targets the homeodomain-leucine Zipper (HD-ZIP III) class III transcription factor that play an important role in lateral root development, axillary meristem initiation and leaf polarity. In M. Truncatula when the drought condition arises, that leads to the reduction in number of lateral root [32] [56]. Plant root growth is greatly influenced by drought stress. When external water supply is limited, structural changes occurred in root system to improve water use efficiency [57]. Therefore, it was concluded that the post 
transcriptional regulation mediated by miR166 is one of the important regulatory mechanism in drought responsive phenomena and root development process [32]. miR528 was found to be downregulated in Zea mays during drought stress [43]. Reactive oxygen species (ROS) such as superoxide radicals $\left(\mathrm{O}_{2}\right)$, hydrogen peroxidase $\left(\mathrm{H}_{2} \mathrm{O}_{2}\right)$ and hydroxyl radicals $(\mathrm{OH})$ are produced in different cellular compartment such as chloroplast, peroxisome and mitochondria [58]. ROS are potentially toxic in nature and various deleterious effects on plant. Plant have evolved defence system like antioxidant enzyme to scavenge ROS [59] [60]. The antioxidant enzymes are superoxide dismutase (SOD), catalase (CAT), peroxidase (POD), ascorbate peroxidase (APX) [61] [62]. miR528 target the peroxidase. It has been observed that the expression of peroxidase was increase when miR528 becomes downregulated. The upregulation of peroxidase promote the removal of excessive $\mathrm{H}_{2} \mathrm{O}_{2}$ which ultimately repress the injury caused by ROS.

Thus, miR528 is presumed to be a regulated by antioxidant (POD) mediated defence system for drought stress response in plant. miR397 was down regulated in O. sativa during drought stress and target the beta fructofuranosidase, that takes part in metabolism of starch and sucrose [49]. The photosynthetic activity and $\mathrm{CO}_{2}$ assimilation in plant and respiration is increased due to exposure of drought stress [33]. Thus, plant protects against drought stress by maintaining required rate of synthesis of carbon hydrogen compounds. The change in expression of miR397 plays major role in $\mathrm{CO}_{2}$ fixation. In Arabidopsis, miR397 was upregulated and target the laccase gene, which was reported to reduce root growth under drought stress [63] [64]. In rice, it was reported that miR169g family of the miR169, was upregulated during drought stress and target the CCAT binding transcription factor. Induction of miR169g was more prominent in root than in shoot [65]. AGO (Argonaute) play a vital factor in miRNA processing. It was found that AGO was targeted by the miRNA168 in Rice and Arabidopsis during drought stress [38] [49].

Osmotic adjustment is another mechanism to tolerate drought stress in plants by accumulation of several osmolytes such as proline, sugar and sugar alcohol such as mannitol, glycine betaine. Proline acts as a free radical scavenger, osmolytes, and stress signal suggesting its multifunctional role in drought stress tolerance [66]. Proline degrade into glutamic acid in higher plants by proline dehydrogenase (PDH) [67]. The miR474 in maize palnt upregulated in drought stress that target the PDH gene leading to the accumulation of the proline in plants, that helps the palnts to protect from the drought stress [43]. miR474 in rice target the protein kinase, kinesin, leucine-rich repeats suggesting its role in post transcriptional regulation of gene expression and upregulated during drought stress condition [49]. miR398 was upregulated in Medicago truncatula [54] and Triticum dicoccoides [68] during drought stress. In Medicago truncatula, the miR398 targets the $\mathrm{Cu} / \mathrm{Zn}$-superoxide dismutase (CSD). The CSD enzyme was found to be involved in ROS detoxification [68]. In Vigna unguiculata miR393 were upregulated in drought stress and target the TAS3-ARF that play an important role in Auxin signalling and lateral root development in plant [69].

\section{Salt Stress Response}

Our planet has large amount of salt in soil accumulated through different sources that limits the agricultural productivity, as it has been estimated that $20 \%$ of agricultural land is salt affected, tremendously decreasing efficiency of the production [7]. High salinity stress leads to disruption of ion homeostasis, imbalance in water potential at the cellular level and finally to the whole plant level. Due to this cellular and molecular change, it leads to various morphological alterations including the yellowness and wilting of leaves, growth arrest, wilting of plants, and even death of the plants. The physiological changes due to salt stress further more induces the ABA synthesis which closes the stomata when transported to guard cell, that ultimately decrease photosynthesis and leads to oxidative damage [70].

\section{Expression of Micro RNAs during Salt Stress}

Large number gene transcript gets up and down regulated during salt stress condition in plant. Therefore, post transcriptional gene silencing plays crucial role in the plant response to salinity stress. miRNA play crucial role to abiotic stress [64] [71]. Various studies on Arabidopsis, rice, and other plant have discovered importance of miRNA in salt stress [70]. Recently, in Arabidopsis several differentially regulated miRNA have been identified in salt stressed tissue. In response to salt stress miR156, miR158, miR159, miR165, miR167, miR168, miR168, miR169, miR171, miR319, miR393, miR394, miR396, miR397 were upregulated in Arabidopsis, thus miRNAs play role in accordance response to salt stress [38]. 


\section{Regulation of Salt Stressed Target Gene Associated miRNAs}

The target of most miRNA are multiple within the same gene family in plants. A recent report revealed that a few of miRNA can regulate the expression of the specific target gene under specific condition [72]. It has also been reported in salinity stressed maize plants that a few of miRNA can regulate the expression of target gene by targeting many transcription factors involved in plant development and organ formation. These transcription factors myb, NAC1 and homeo domain-leuchine-zipper proteins (HD-ZIP) were predicted as the target of zma$\mathrm{miR} 159 \mathrm{a} / \mathrm{b}$, zma-miR164a/b/c/d and zma-miR1661/m respectively. The similar reports were made in Arabidopsis and rice [73]. Few other transcription factors include MADS-box protein and zinc-finger protein, which are also predicted for target gene of miRNA have also been reported as salt responsive factor in plant [74], [75]. In addition to transcription factor, a number of miRNA target gene which encode protein involved in various metabolic pathway or physiological process directly or indirectly in plants [70]. Besides, the miRNA which target to regulate the NADP dependent mallic enzyme (NADP-ME) and cytochrome oxidase, are found to be salt responsive in plant [76] [77].

In O. Sativa, miR393 target the phytosulfokinne receptor precursor, transport inhibitor response/protein oxidoreductase that plays a significant role in Auxin signalling during salt stress [38]. miR396c target the heat shock $70 \mathrm{kda}$ protein (HSP), TBP associated 59kDa subunit protein, Leucine rich repeat family protein ubiquitin protein ligase caps, jasmonate o-ethyl transferase, which is involve in plant growth and development under salt stress [78]. miR2001, miR2004, miR2006 which were upregulated and target Hypothetical protein, (Protein GPR107 precursor) (EMB2745), (exonuclease FAD binding domain containing protein) Hypothetical protein conserved hypothetical protein respectively during salt stress [79]. miR2003 target the Heat repeat family protein expressed ribosomal protein S11 containing protein and upregulated during salt stress [79].

The targets sulfurylase and ASP1 gene are regulated by miR395 in salt induced soybean line under sulphate starvation condition. Therefore the role of miR395 may be in non specific salt stressed responding pathway, such as the maintenance of energy supply [80]. The target of Artichok, cca-miR397 and 399 were homologous to members of laccase gene family, which are also participating in salt stress response [81]. Laccase are multicopper containing glycoprotein, present in plant and it helps in liginin formation in plant. It has been reported that the expression level of laccase gene is enhanced by high concentration of $\mathrm{NaCl}$ in tomato, maize and Arabidopsis root [63] [82]. In Artichoke, reduced expression of miR397a in root during salt stress might possibly lead to enhanced expression of laccase [81]. miRNA cca-novel-18 regulates by targeting aspartic proteinase APA1. It was observed that the expression of target superoxide dismutase decrease with slightly increase in expression of miR398 in Arabidopsis during salt stress [83] [84]. Another important target AGROUNAUTAE1 (AGO1) gene, which encodes the RNA slicer enzyme in the miRNA pathway is regulated by miR168 [85] [86]. Both AGO1 and miR168 are crucial in maintaining equilibrium between the target miRNA and their targeted gene. The miR168 has been also found in salt stress in maize [80].

In Arbidopsis thaliana, miR156 and miR159 target the Squamosa promoter binding protein like 11 and MYB and TCP transcription factor respectively which found to be upregulated under salt stress [73] [87]. miR165 targets the class III HD-ZIP transcription factor was upregulated and involved in leaf development under salt stress [73]. miR167 was reported to be upregulated and target the Auxin response factor 6 and 8 (ARF6 and ARF8). ARF play important role in gynoecium and stamen development [88]. miR319 was upregulated and target the TCP transcription factor during salt stress in Arbidopsis thaliana. TCP transcription factor involve in morphogenesis of the shoot lateral organ [89]. Whereas, the F-Box protein:bHLH (basic helix-loop-helix) transcription factor is the salt responsive target of miR393 which is upregulated in Arbidopsis thaliana [73]. miR417 has several targets viz. RNAdirected RNA polymerase, SNF7 family protein containing pFam domain hydrolase, cell expansion protein, SNF domain/helicase domain protein, C2-domain containing protein, cell expansion protein, Auxin response transcription factors, which are downregulated in Arbidopsis thaliana [90].

In contrast, miR397 and miR398 target Rhodenase kinesin like protein B and inter prodomain protein of unknown function DUF266, respectively which are upregulated in Arabidopsis thaliana under salt stress [63] [84]. miR162 was upegulated and target the RNAse III CAF protein Endonuclease Dicer, cytochrome P450 in Zea mays during salinity stress. Dicer plays an important role in miRNA processing [91]. miRNA167 was down regulated and target the Auxin response factor in salt stress in Zea mays [92]. Homeodomain leucine Zipper protein (HD-ZIP), a salt responsive target of miR166 which is downregulated by miRNA in Zea mays [93]. The target of miR1507a are splicing factor Yt 521B, NBS-LRR resistance protein RGH1 cytosine specific methyl transferase is found to be salt responsive in Glycine max [94]. 
In Populus trichocarpa, miR482.2 are upregulated and miR1445 are downregulated and-target the disease resistance protein and dihydropyrimidinase respectively, which involve in cambium differentiation in stem development during salinity stress [95].

\section{Common miRNA Expression for Both Drought and Salinity Stress}

There are several miRNA which are participate in both salt and drought stress. In Arabidopsis thaliana, the miRNAs such as miR159, miR167, miR168, miR169, miR393, miR396, miR397 which are participate both in salt and drought condition. There are some miRNA which are different in action under different stress condition, i.e. some miRNA which are upregulated in drought stress, the same miRNA are down regulated in salt stress. The miR393 during drought stress was upregulated and targets the TIR1, which is a positive regulator of the auxin signalling but in salt stress it target the F-Box protein (bHLH) transcription factor. In Zea mays under drought stress, the miR167 becomes downregulate and targets the PLD (phospholipase D) which is appositive regulator of the drought stress resistance but under salt stress the miR167 target the ARF (Auxin Response Factor). In O. sativa, the two miRNA (miR393 and miR396) are function in both the stress conditions. The miR393 under the both the stress i.e. salt and drought stress are upregulated and target the TIR1, which is response to auxin signalling. Importantly the miR396 under salt stress target the heat shock $70 \mathrm{kDa}$ protein which is a chaperon helps in protein folding for correct function of protein.

The miRNA involved in drought stress were categorically divided on the basis of their mechanism of action and represented in pie chart which is determined from the given data of Table 1 and Table 2 for easy understanding (Figure 3). It was observed 28\% are involved in ABA signalling and response, $14.2 \%$ in auxin signal

\begin{tabular}{|c|c|c|c|c|}
\hline $\begin{array}{l}\text { Micro RNA } \\
\text { family }\end{array}$ & Target & $\begin{array}{l}\text { Response under } \\
\text { drought }\end{array}$ & Mechanism of action & Reference \\
\hline \multicolumn{5}{|l|}{ Oryza sativa } \\
\hline $\operatorname{miR} 167$ & ARF & Upregulated & ABA response & [42] \\
\hline $\operatorname{miR} 168$ & $\mathrm{AGO}$ & Downregulated & miRNA processing & [49] \\
\hline $\operatorname{miR} 169 \mathrm{~g}$ & CCAT binding transcription factor & Upregulate & Unkown & [69] \\
\hline $\operatorname{miR} 393$ & TIR1 & Upregulated & Auxin signalling & [48] \\
\hline $\operatorname{miR} 396$ & GRF & Downregulated & Leaf development & [49] \\
\hline $\operatorname{miR} 397$ & $\beta$-fructofuranosidase & Downregulated & $\mathrm{CO}_{2}$ fixation & [49] \\
\hline $\operatorname{miR} 474$ & PPR (Protein kinase, kinesin, leucine-rich repeat) & Upregulated & Controlling organelle gene expression & [49] \\
\hline \multicolumn{5}{|c|}{ Arabidopsis thaliana } \\
\hline $\operatorname{miR} 159$ & MYB & Upregulated & ABA signalling and osmotic stress tolerance & [39]-[41] \\
\hline $\operatorname{miR} 160$ & ARF (Auxin response factor) & Not known & $\mathrm{ABA}$ response & [46] \\
\hline $\operatorname{miR} 167$ & ARF & Upregulated & ABA response & {$[38]$} \\
\hline $\operatorname{miR} 168$ & AGO & Upregulated & miRNA processing & [38] \\
\hline $\operatorname{miR} 169$ & NFYA & Downregulated & ABA response and controlling stomotal aperture & [45] \\
\hline $\operatorname{miR} 393$ & TIR1(Transport inhibitor response) & Upregulated & Auxin signalling & [64] \\
\hline $\operatorname{miR} 396$ & GRF(Growth regulating factor) & Upregulated & Leaf development & [38] \\
\hline $\operatorname{miR} 397$ & Laccase & Upregulated & Not known & {$[64]$} \\
\hline \multicolumn{5}{|l|}{ Zea mays } \\
\hline $\operatorname{miR} 167$ & PLD (Phospholipase D) & Downregulated & $\mathrm{ABA}$ response and controlling stomotal movement & [43] \\
\hline $\operatorname{miR} 474$ & PDH(Proline dehydrogenase) & Upregulated & Proline accumulation & [43] \\
\hline $\operatorname{miR} 528$ & POD(Peroxidase) & Downregulated & ROS detoxification & [43] \\
\hline \multicolumn{5}{|c|}{ Medicago truncatula } \\
\hline $\operatorname{miR} 166$ & HD-Zip (Homeodomain leucine zipper) & Upregulated & Root and nodule development & [54] \\
\hline $\operatorname{miR} 398$ & CSD (Cu/Zn-superoxide dismutase) & Upregulated & ROS detoxification & {$[54]$} \\
\hline \multicolumn{5}{|c|}{ Vigna unguiculata } \\
\hline $\operatorname{miR} 390$ & TAS3-ARF & Upregulated & Auxin signalling and lateral root development & [69] \\
\hline
\end{tabular}




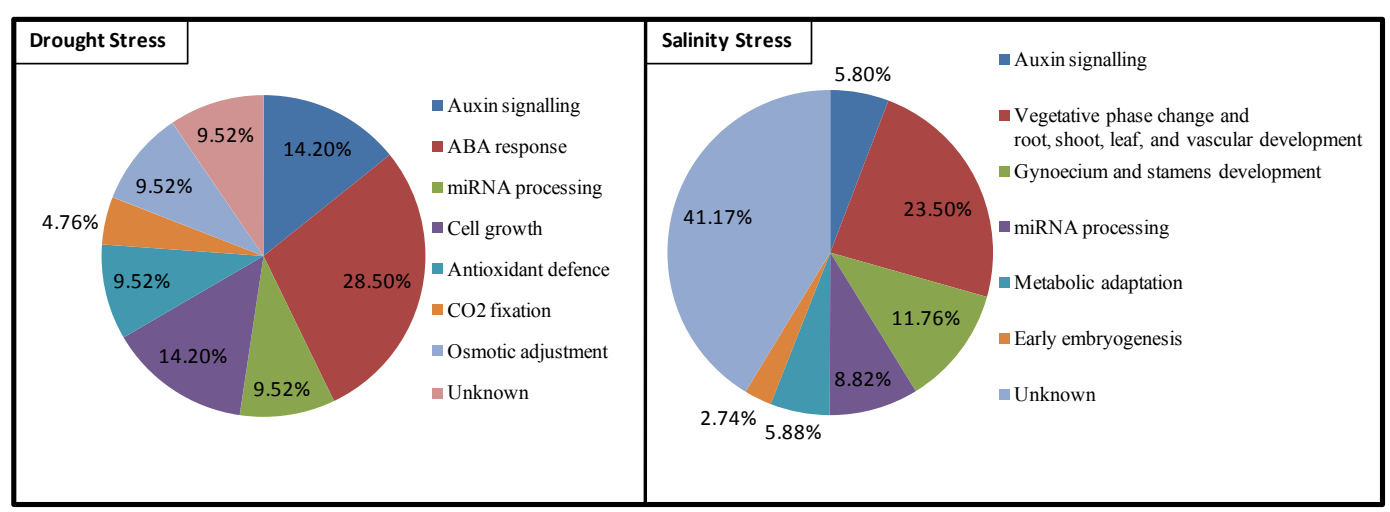

Figure 3. Pie Charts show the percentage of miRNA control the drought and salinity stress based on their mechanism of action.

Table 2. miRNA participate in salinity stress.

\begin{tabular}{|c|c|c|c|c|}
\hline miRNA & Target & Response under salt & Mechanism of action & Ref. \\
\hline \multicolumn{5}{|l|}{ Oryza sativa } \\
\hline $\operatorname{miR} 393$ & $\begin{array}{l}\text { Phytosulfokinne receptor precursor, transport inhibi- } \\
\text { tor Response/protein oxidoreductase. }\end{array}$ & Unknown & Auxin signalling & {$[38]$} \\
\hline $\operatorname{miR} 396 \mathrm{c}$ & $\begin{array}{c}\text { Heat shock } 70 \mathrm{kda} \text { protein, TBP associated } 59 \mathrm{kDa} \\
\text { subunit protein, Leucine rich repeat family protein } \\
\text { ubiquitin protein ligase caps, } \\
\text { jasmonate o-ethyl transferase. }\end{array}$ & Upregulated & $\begin{array}{l}\text { Plant growth and } \\
\text { development }\end{array}$ & {$[78]$} \\
\hline $\operatorname{miR} 2001$ & Hypothetical protein. Protein GPR107 precursor & Unknown & Unknown & [79] \\
\hline $\operatorname{miR} 2003$ & $\begin{array}{l}\text { Heat repeat family protein expressed ribosomal } \\
\text { protein S11 containing protein. }\end{array}$ & Down regulated & Unknown & {$[79]$} \\
\hline $\operatorname{miR} 2004$ & $\begin{array}{l}\text { EMB2745, exonuclease FAD binding domain } \\
\text { containing protein. }\end{array}$ & Upregulated & Unknown & {$[79]$} \\
\hline $\operatorname{miR} 2006$ & Hypothetical protein conserved hypothetical protein. & Upregulated & Unknown & {$[79]$} \\
\hline \multicolumn{5}{|c|}{ Arbidopsis thaliana } \\
\hline $\operatorname{miR} 156$ & Squamosa promoter binding protein like 11 & Upregulated & $\begin{array}{l}\text { Vegetative phase change } \\
\text { and root development }\end{array}$ & {$[87]$} \\
\hline $\operatorname{miR} 158$ & F-Box family protein & Upregulated & Not known & {$[38]$} \\
\hline $\operatorname{miR} 159$ & MYB and TCP transcription factor & Upregulated & $\begin{array}{l}\text { Short day flowering } \\
\text { time; anther development }\end{array}$ & {$[73]$} \\
\hline $\operatorname{miR} 165$ & Class III HD-ZIP transcription factor & Upregulated & Development (leaf) & {$[73]$} \\
\hline $\operatorname{miR} 167$ & Auxin response factor 6 and 8 & Upregulated & $\begin{array}{l}\text { Gynoecium and stamens } \\
\text { development }\end{array}$ & {$[88]$} \\
\hline $\operatorname{miR} 168$ & AGOI (AGRONAUTE I) & Upregulated & miRNA processing & {$[86]$} \\
\hline $\operatorname{miR} 169$ & $\begin{array}{l}\text { CCAT-binding transcription factor } \\
\text { (CBF-B/NF-YA) FAMILY PROTEIN }\end{array}$ & Upregulated & Unknown & {$[38]$} \\
\hline $\operatorname{miR} 319$ & TCP transcription factor & Upregulated & Morphogenesis of shoot & [89] \\
\hline $\operatorname{miR} 393$ & $\begin{array}{c}\text { F-Box protein:bHLH (basic helix-loop-helix) } \\
\text { transcription factor }\end{array}$ & Upregulated & Auxin signalling & {$[73]$} \\
\hline $\operatorname{miR} 394$ & F-Box family protein. & Upregulated & $\begin{array}{c}\text { Floral initiation and } \\
\text { development }\end{array}$ & {$[71]$} \\
\hline $\operatorname{miR} 396$ & GRF2 transcription factor & Down regulated & $\begin{array}{c}\text { Regulate cell } \\
\text { expansion in leaf }\end{array}$ & {$[38]$} \\
\hline $\operatorname{miR} 397$ & Rhodenase like protein; kinesin like protein B & Upregulate & Not known & [63] \\
\hline $\operatorname{miR} 398$ & LAC2 (Lccase); B-6 tubulin & Upregulated & Unknown & [84] \\
\hline
\end{tabular}




\begin{tabular}{|c|c|c|c|c|}
\hline \multicolumn{5}{|l|}{ Continued } \\
\hline $\operatorname{miR} 417$ & $\begin{array}{l}\text { Inter prodomain protein of unknown function } \\
\text { DUF266. C2-domain containing protein,SNF7 family } \\
\text { protein, contains pFam domain hydrolase, cell } \\
\text { expansion protein, RNAdirected RNA polymerase, } \\
\text { SNF domain/helicase domain protein, Auxin } \\
\text { response transcription factor }\end{array}$ & Down regulated & Unknown & {$[90]$} \\
\hline \multicolumn{5}{|l|}{ Zea mays } \\
\hline $\operatorname{miR} 156$ & SBP domain protein & Down regulated & $\begin{array}{l}\text { Vegetative phase change } \\
\text { and root development }\end{array}$ & {$[38]$} \\
\hline $\operatorname{miR} 162$ & $\begin{array}{l}\text { RNAse III CAF protein, Endonuclease } \\
\text { Dicer, cytochrome P450 }\end{array}$ & Upregulated & miRNA processing & [91] \\
\hline $\operatorname{miR} 164$ & NAC domain NAC 1 & Down regulated & Early embryogenesis & {$[80]$} \\
\hline $\operatorname{miR} 166$ & Homeodomain leucine Zipper protein (HD-ZIP) & Not known & Vascular development. & [93] \\
\hline $\operatorname{miR} 167$ & Auxin response factor & Down regulated & $\begin{array}{c}\text { Gynoecium and stamens } \\
\text { development }\end{array}$ & [92] \\
\hline $\operatorname{miR} 168$ & PZE40 Protein, cytoplasmic aldolase AGO 1 & Upregulated & miRNA processing & {$[80]$} \\
\hline $\operatorname{miR} 172$ & Gamma tubulin & Not known & Not known & {$[80]$} \\
\hline $\operatorname{miR} 395$ & ATP sulfurylase & Upregulated & $\begin{array}{l}\text { Maintenance of energy } \\
\text { supply (Physiological and } \\
\text { metabolic adaptation) }\end{array}$ & {$[80]$} \\
\hline $\operatorname{miR} 396$ & Cytochrome oxidase subunit & Down regulated & $\begin{array}{l}\text { Protect photosynthesis } \\
\text { (physiological and } \\
\text { metabolic adaptation) }\end{array}$ & $\begin{array}{l}{[76]} \\
{[77]}\end{array}$ \\
\hline \multicolumn{5}{|l|}{ Glycine $\max$} \\
\hline $\operatorname{miR} 1507 \mathrm{a}$ & $\begin{array}{l}\text { Splicing factor Yt 521B, NBS-LRR resistance protein } \\
\text { RGH1 cytosine specific methyl transferase }\end{array}$ & Unknown & Unknown & [94] \\
\hline $\operatorname{miR} 166 b$ & DNA binding protein class III HD zip protein 4 and 8 & Unknown & Unknown & [94] \\
\hline $\operatorname{miR} 395$ & $\begin{array}{l}\text { ATP Sulphurylase, Beta glucosidase, } \\
\text { disease resistance protein. }\end{array}$ & Unknown & Unknown & [94] \\
\hline \multicolumn{5}{|c|}{ Populous trichocarpa } \\
\hline $\operatorname{miR} 482.2$ & Disease resistance protein & Upregulated & Unknown & [95] \\
\hline $\operatorname{miR} 1445$ & Dihydropyrimidinase & Down regulated & $\begin{array}{l}\text { Cambium differentiation in } \\
\text { stem (development) }\end{array}$ & {$[95]$} \\
\hline
\end{tabular}

ling, $9.52 \%$ in miRNA processing, $14.2 \%$ in cell growth, $9.52 \%$ in antioxidant defence, $4.76 \%$ in $\mathrm{CO}_{2}$ fixation and $9.52 \%$ in osmotic adjustment. Similarly for salinity stress, $5.8 \%$ are involved in auxin signalling, $23.5 \%$ in vegetative phase change and root, shoot, leaf and vascular development, $11.76 \%$ in gynoecium and stamens development, $8.82 \%$ in metabolic adaptation, $2.74 \%$ in early embryogenesis and $41.17 \%$ not known (Figure 3).

\section{Conclusion and Future Perspectives}

RNAi has recently become a highly effective and powerful tool of functional genomics for silencing the gene expression for crop improvement. The regulatory role of miRNAs in plants is definitely a subject that will require much more investigation in plant biology. As presented in this review, several miRNAs have been determined to be commonly involved in drought and salinity stress responses and also plant development. miRNAs regulate numerous transcription factors during in response to different stresses. For many drought and salinity stress-related genes, miRNAs function as critical post-transcription modulator for their expression. This characterization provides a view for future analysis of miRNAs involved in drought stress resistance and will be useful for improvement of drought tolerance in plants. Although a number of drought-related miRNAs have been identified, their precise role remains to be verified. Additional strategies need to be employed to investigate the functions of miRNAs and their associated signalling pathways and gene networks under both drought and salinity stress. 


\section{References}

[1] Battisti, D.S. and Naylor, R.L. (2009) Historical Warnings of Future Food Insecurity with Unprecedented Seasonal Heat. Science, 323, 240-244. http://www.sciencemag.org/content/323/5911/240.long http://dx.doi.org/10.1126/science.1164363

[2] Takeda, S. and Matsuoka, M. (2008) Genetic Approaches to Crop Improvement: Responding to Environmental and Population Changes. Nature Reviews Genetics, 9, 444-457. http://www.nature.com/nrg/journal/v9/n6/full/nrg2342.html http://dx.doi.org/10.1038/nrg2342

[3] Singh, A.K., Ansari, M.W., Pareek, A. and Singla-Pareek, S.L. (2008) Raising Salinity Tolerant Rice: Recent Progress and Future Perspectives. Physiology and Molecular Biology of Plants, 14, 137-154.

http://www.ncbi.nlm.nih.gov/pmc/articles/PMC3550660/pdf/12298_2008_Article_13.pdf http://dx.doi.org/10.1007/s12298-008-0013-3

[4] Lindemose, S., O'Shea, C., Jensen, M.K. and Skriver, K. (2013) Structure, Function and Networks of Transcription Factors Involved in Abiotic Stress Responses. International Journal of Molecular Sciences, 14, 5842-7588. http://www.ncbi.nlm.nih.gov/pmc/articles/PMC3634440/pdf/ijms-14-05842.pdf http://dx.doi.org/10.3390/ijms14035842

[5] Williams, M., Clark, G., Sathasivan, K. and Islam, A.S. (2004) RNA Interference and Its Application in Crop Improvement. http://citeseerx.ist.psu.edu/viewdoc/download?doi=10.1.1.98.1069\&rep=rep1\&type=pdf

[6] Kumar, P., Kamle, M. and Pandey, A. (2012) RNAi: New Era of Functional Genomics for Crop Improvement. Frontiers on Recent Developments in Plant Science, 1, 24-38.

http://www.researchgate.net/publication/229090799_RNAi_New_Era_of_Functional_Genomics_for_Crop_Improvem ent

[7] Younis, A., Siddique, M.I., Kim, C.K. and Lim, K.B. (2014) RNA Interference (RNAi) Induced Gene Silencing: A Promising Approach of Hi-Tech Plant Breeding. International Journal of Biological Sciences, 10, 1150-1158.

http://www.ijbs.com/v10p1150.pdf http://dx.doi.org/10.7150/ijbs.10452

[8] Navarro, L., Dunoyer, P., Jay, F., Arnold, B., Dharmasiri, N., Estelle, M., Voinnet, O. and Jones, J. D. (2006) A Plant miRNA Contributes to Antibacterial Resistance by Repressing Auxin Signaling. Science, 312, 436-439. http://www.sciencemag.org/content/312/5772/436.full.pdf http://dx.doi.org/10.1126/science.1126088

[9] Qu, J., Ye, J. and Fang, R. (2007) Artificial microRNA-Mediated Virus Resistance in Plants. Journal of Virology, 81, 6690-6699. http://jvi.asm.org/content/81/12/6690.full.pdf + html http://dx.doi.org/10.1128/JVI.02457-06

[10] Ali, N., Datta, K.S. and Datta, K. (2010) RNA Interference in Designing Transgenic Crops. Landes Biosciences, 1, 207-213. http://www.tandfonline.com/doi/pdf/10.4161/gmcr.1.4.13344 http://dx.doi.org/10.4161/gmcr.1.4.13344

[11] Tang, G. and Galili, G. (2004) Using RNAi to Improve Plant Nutritional Value: From Mechanism to Application. Trends in Biotechnology, 22, 463-469. http://www.sciencedirect.com/science/article/pii/S0167779904002021 http://dx.doi.org/10.1016/j.tibtech.2004.07.009

[12] Segal, G., Song, R. and Messing, J. (2003) A New Opaque Variant of Maize by a Single Dominant RNA-Interference-Inducing Transgene. Genetics, 165, 387-397. http://www.genetics.org/content/165/1/387.full.pdf

[13] Williams, M., Clark, G., Sathasivan, K. and Islam, A.S. (2004) RNA Interference and Its Application in Crop Improvement. Plant Tissue Culture and Biotechnology, 1-18. http://citeseerx.ist.psu.edu/viewdoc/download?doi=10.1.1.98.1069\&rep=rep1\&type=pdf

[14] Regina, A., Bird, A., Topping, D., Bowden, S., Freeman, J., Barsby, T., Kosar-Hashemi, B., Li, Z., Rahman, S. and Morell, M. (2006) High-Amylose Wheat Generated by RNA Interference Improves Indices of Large-Bowel Health in Rats. Proceedings of the National Academy of Sciences of the United States of America, 103, 3546-3551. http://www.pnas.org/content/103/10/3546.full.pdf

[15] Shimada, T., Otani, M., Hamada, T. and Kim, S. (2006) Increase of Amylose Content of Sweetpotato Starch by RNA Interference of the Starch Branching Enzyme II Gene (IbSBEII). Plant Biotechnology, 23, 85-90.

http://www.wdc-jp.biz/pdf_store/jspcmb/pdf/pb23_1/23_85.pdf http://dx.doi.org/10.5511/plantbiotechnology.23.85

[16] Davuluri, G.R., Tuinen, A., Fraser, P.D., Manfredonia, A., Newman, R., Burgess, D., Brummell, D.A., King, S.R., Palys, J., Uhlig, J., Bramley, P.M., Pennings, H.M. and Bowler, C. (2005) Fruit-Specific RNA-Imediated Suppression of DET1 Enhances Carotenoid and Flavonoid Content in Tomatoes. Nature Biotechnology, 23, 890-895. http://www.ncbi.nlm.nih.gov/pmc/articles/PMC3855302/pdf/nihms-532873.pdf 
http://dx.doi.org/10.1038/nbt1108

[17] Yu, B., Lydiate, D.J., Young, L.W., Schafer, U.A. and Hannoufa, A. (2007) Enhancing the Carotenoid Content of Brassica napus Seeds by Down Regulating Lycopene Epsilon Cyclase. Transgenic Research, 17, 573-585. http://link.springer.com/article/10.1007\%2Fs11248-007-9131-x http://dx.doi.org/10.1007/s11248-007-9131-x

[18] Ogita, S., Uefuji, H., Yamaguchi, Y., Koizumi, N. and Sano, H. (2003) Producing Decaffeinated Coffee Plants. Nature, 423, 823. http://www.nature.com/nature/journal/v423/n6942/full/423823a.html http://dx.doi.org/10.1038/423823a

[19] Nunes, A., Vianna, G., Cuneo, F., Amaya-Farfán, J., de Capdeville, G., Rech, E.L. and Aragão, F.J. (2006) RNAi-Mediated Silencing of the Myo-Inositol-1-Phosphate Synthase Gene (GmMIPS1) in Transgenic Soybean Inhibited Seed Development and Reduced Phytate Content. Planta, 224, 125-132. http://link.springer.com/article/10.1007\%2Fs00425-005-0201-0 http://dx.doi.org/10.1007/s00425-005-0201-0

[20] Kuwano, M., Ohyama, A., Tanaka, Y., Mimura, T., Takaiwa, F. and Yoshida, K.T. (2006) Molecular Breeding for Transgenic Rice with Low-Phytic-Acid Phenotype through Manipulating Myo-Inositol 3-Phosphate Synthase Gene. Molecular Breeding, 18, 263-272. http://link.springer.com/article/10.1007\%2Fs11032-006-9038-x\#page-1 http://dx.doi.org/10.1007/s11032-006-9038-x

[21] Guo, S. and Kemphues, K.J. (1995) Par-1, a Gene Required for Establishing Polarity in C. elegans Embryo, Encodes a Putative Ser/Thr Kinase That Is Asymmetrically Distributed. Cell, 81, 611-620.

http://www.sciencedirect.com/science/article/pii/0092867495900829 http://dx.doi.org/10.1016/0092-8674(95)90082-9

[22] Tabra, H., Grishok, H. and Mello, C.C. (1998) RNAi in C. elegans Soaking in the Genome Science. Science, 282, 430431. http://www.sciencemag.org/content/282/5388/430.long http://dx.doi.org/10.1126/science.282.5388.430

[23] Bernstein, E., Cauday A.A., Hammond, S.M. and Hannon, G. (2001) Role for a Bidentate Ribonuclease in the Initiation Steps of RNA Interference. Nature, 409, 363-366.

http://www.nature.com/nature/journal/v409/n6818/full/409363a0.html http://dx.doi.org/10.1038/35053110

[24] Agrawal, N., Dasaradhi, P.V.N., Mohommed, A., Malhotra, P., Bhatnagar, R.K. and Mukherjee, S.K. (2003) RNA Interference: Biology, Mechanism and Application. Microbiology and Molecular Biology, 67, 657-685. http://www.ncbi.nlm.nih.gov/pmc/articles/PMC309050/pdf/0025.pdf http://dx.doi.org/10.1128/MMBR.67.4.657-685.2003

[25] Schwarz, D., Tomari, Y. and Zamore, P. (2004) The RNA-Induced Silencing Complex Is a Mg2+-Dependent Endonuclease. Current Biology, 14, 787-791. http://www.ncbi.nlm.nih.gov/pubmed/15120070 http://dx.doi.org/10.1016/i.cub.2004.03.008

[26] Nykänen, A., Haley, B. and Zamore, P. (2001) ATP Requirements and Small Interfering RNA Structure in the RNA Interference Pathway. Cell, 107, 309-321.

http://ac.els-cdn.com/S0092867401005475/1-s2.0-S0092867401005475-main.pdf? tid=f619ec5a-18bd-11e5-9f01-000 00aacb362\&acdnat $=1434964166 \_4 \mathrm{c} 70 \mathrm{e} 734585 \mathrm{~d} 0 \mathrm{c} 8 \mathrm{edee} 927 \mathrm{c} 722 \mathrm{cc} 115 \mathrm{~b}$ http://dx.doi.org/10.1016/S0092-8674(01)00547-5

[27] Lipardi, C., Wei, Q. and Paterson, B.M. (2001) RNAi as Random Degradative PCR siRNAs, Primers Convert mRNA in dsRNA That Are Degraded to Generate New siRNAs. Cell, 101, 297-307.

http://www.sciencedirect.com/science/article/pii/S0092867401005372 http://dx.doi.org/10.1016/S0092-8674(01)00537-2

[28] Sijen, T., Fleenor, J., Simmer, F., Thijssen, K.L., Parrish, S. and Timmsons, L. (2001) On the Role of RNA Amplification in dsRNA Triggered Gene Silencing. Cell, 107, 465-476. http://www.sciencedirect.com/science/article/pii/S0092867401005761 http://dx.doi.org/10.1016/S0092-8674(01)00576-1

[29] Ahlquist, P. (2002) RNA Dependant RNA Polymerase, Viruses and RNA Silencing. Science, 296, 1270-1273. http://www.sciencemag.org/content/296/5571/1270.long http://dx.doi.org/10.1126/science.1069132

[30] Jagtap, U.B., Gurav, R.G. and Bapat, V.A. (2011) Role of RNA Interference in Plant Improvement. Naturwissenschaften, 98, 473-492. http://link.springer.com/article/10.1007\%2Fs00114-011-0798-8 http://dx.doi.org/10.1007/s00114-011-0798-8

[31] Gupta, K., Sengupta, A., Saha, J. and Gupta, B. (2014) The Attributes of RNA Interference in Relation to Plant Abiotic Stress Tolerance. Gene Technology, 3, 110. 
http://omicsgroup.org/journals/the-attributes-of-rna-interference-in-relation-to-plant-abiotic-stress-tolerance-2329-6682 .1000110.pdf

[32] Ding, D., Zhang, L., Wang, H., Liu, Z., Zhang, Z. and Zheng, Y. (2009) Differential Expression of miRNAs in Response to Salt Stress in Maize Roots. Annals of Botany, 103, 29-38.

http://www.ncbi.nlm.nih.gov/pmc/articles/PMC2707283/pdf/mcn205.pdf http://dx.doi.org/10.1093/aob/mcn205

[33] Shinozaki, K. and Yamaguchi-Shinozaki, K. (2007) Gene Networks Involved in Drought Stress Response and Tolerance. Journal of Experimental Botany, 58, 221-227. http://jxb.oxfordjournals.org/content/58/2/221.full.pdf $+\mathrm{html}$ http://dx.doi.org/10.1093/jxb/erl164

[34] Cai, S., Jiang, G., Ye, N., Chu, Z., Zhang, J. and Zhu, G. (2015) A Key ABA Catabolic Gene, OsABA8ox3, Is Involved in Drought Stress Resistance in Rice. PLOS ONE, 10, e0116646. http://www.ncbi.nlm.nih.gov/pmc/articles/PMC4315402/pdf/pone.0116646.pdf http://dx.doi.org/10.1371/journal.pone.0116646

[35] Sahoo, K.K., Tripathi, A.K., Pareek, A. and Singla-Pareek, S.L. (2013) Taming Drought Stress in Rice through Genetic Engineering of Transcription Factors and Protein Kinases. Plant Stress, 7, 60-72. http://www.globalsciencebooks.info/JournalsSup/images/Sample/PS 7\%28SI1\%2960-720.pdf

[36] Bartels, D. and Sunkars, R. (2005) Drought and Salt Tolerance in Plants. Critical Reviews in Plant Science, 24, 23-58. http://www.tandfonline.com/doi/pdf/10.1080/07352680590910410\#.VZUliBuqqko http://dx.doi.org/10.1080/07352680590910410

[37] Hirayama, T. and Shinozaki, K. (2007) Perception and Transduction of Abscisic Acid Signals: Keys to the Function of the Versatile Plant Hormone ABA. Trends in Plant Science, 12, 343-351. http://dx.doi.org/10.1016/j.tplants.2007.06.013

[38] Liu, H.H., Tian, X., Li, Y.J., Wu, C.A. and Zheng, C.C. (2008) Microarray-Based Analysis of Stress-Regulated microRNAs in Arabidopsis thaliana. RNA, 14, 836-843. http://www.ncbi.nlm.nih.gov/pmc/articles/PMC2327369/pdf/836.pdf http://dx.doi.org/10.1261/rna.895308

[39] Reyes, J.L. and Chua, N.H. (2007) ABA Induction of miR159 Controls Transcript Levels of Two MYB Factors during Arabidopsis Seed Germination. The Plant Journal, 49, 592-606. http://onlinelibrary.wiley.com/doi/10.1111/j.1365-313X.2006.02980.x/epdf http://dx.doi.org/10.1111/j.1365-313X.2006.02980.x

[40] Allen, R.S., Li, J.Y., Alonso-Peral, M.M., White, R.G., Gubler, F. and Millar, A.A. (2010) MicroR159 Regulation of Most Conserved Targets in Arabidopsis Has Negligible Phenotypic Effects. Silence, 1, 18. http://www.ncbi.nlm.nih.gov/pmc/articles/PMC2988730/pdf/1758-907X-1-18.pdf http://dx.doi.org/10.1186/1758-907X-1-18

[41] Abe, H., Urao, T., Ito, T., Seki, M., Shinozaki, K. and Yamaguchi-Shinozaki, K. (2003) Arabidopsis AtMYC2 (bHLH) and AtMYB2 (MYB) Function as Transcriptional Activators in Abscisic Acid Signaling. The Plant Cell, 15, 63-78. http://www.plantcell.org/content/15/1/63.full.pdf + html http://dx.doi.org/10.1105/tpc.006130

[42] Liu, Q., Zhang, Y.C., Wang, C.Y., Luo, Y.C., Huang, Q.J., Chen, S.Y., Zhou, H., Qu, L.H. and Chen, Y.Q. (2009) Expression Analysis of Phytohormone Regulated microRNAs in Rice, Implying Their Regulation Roles in Plant Hormone Signaling. FEBS Letters, 583, 723-728. http://www.sciencedirect.com/science/article/pii/S0014579309000428 http://dx.doi.org/10.1016/j.febslet.2009.01.020

[43] Wei, L., Zhang, D., Xiang, F. and Zhang, Z. (2009) Differentially Expressed miRNAs Potentially Involved in the Regulation of Defense Mechanism to Drought Stress in Maize Seedlings. International Journal of Plant Sciences, 170, 979-989. http://www.lcsciences.com/news/differentially-expressed-mirnas-potentially-involved-in-the/ http://dx.doi.org/10.1086/605122

[44] Zhang, W., Yu, L., Zhang, Y. and Wang, X. (2005) Phospholipase D in the Signalling Networks of Plant Response to Abscisic Acid and Reactive Oxygen Species. Biochimica et Biophysica Acta, 1736, 1-9. http://www.sciencedirect.com/science/article/pii/S1388198105001551

[45] Li, W.X., Oono, Y., Zhu, J., He, X.J., Wu, J.M., Iida, K., Lu, X.Y., Cui, X., Jin, H. and Zhu, J.K. (2008) The Arabidopsis NFYA5 Transcription Factor Is Regulated Transcriptionally and Posttranscriptionally to Promote Drought Resistance. The Plant Cell, 20, 2238-2251. http://www.ncbi.nlm.nih.gov/pmc/articles/PMC2553615/pdf/tpc2002238.pdf http://dx.doi.org/10.1105/tpc.108.059444

[46] Liu, P.P., Montgomery, T.A., Fahlgren, N., Kasschau, K.D., Nonogaki, H. and Carrington, J.C. (2007) Repression of AUXIN RESPONSE FACTOR 10 by microRNA160 Is Critical for Seed Germination and Post-Germination Stages. The Plant Journal, 52, 133-146. http://onlinelibrary.wiley.com/doi/10.1111/j.1365-313X.2007.03218.x/epdf 
http://dx.doi.org/10.1111/j.1365-313X.2007.03218.x

[47] Dharmasiri, S. and Estelle, M. (2002) The Role of Regulated Protein Degradation in Auxin Response. Plant Molecular Biology, 49, 401-409. http://www.ncbi.nlm.nih.gov/pubmed/12036263 http://dx.doi.org/10.1007/978-94-010-0377-3 11

[48] Xia, K., Wang, R., Ou, X., Fang, Z., Tian, C., Duan, J., Wang, Y. and Zhang, M. (2012) OsTIR1 and OsAFB2 Downregulation via osmiR393 Overexpression Leads to More Tillers, Early Flowering and Less Tolerance to Salt and Drought in Rice. PLoS ONE, 7, e30039.

http://www.ncbi.nlm.nih.gov/pmc/articles/PMC3254625/pdf/pone.0030039.pdf http://dx.doi.org/10.1371/journal.pone.0030039

[49] Zhou, L.G., Liu, Y.H., Liu, Z.C., Kong, D.Y., Duan, M. and Luo, L.J. (2010) Genome-Wide Identification and Analysis of Drought-Responsive microRNAs in Oryza sativa. Journal Experimental Botany, 61, 4157-4168.

http://jxb.oxfordjournals.org/content/61/15/4157.full.pdf + html http://dx.doi.org/10.1093/jxb/erq237

[50] Wang, T., Chen, L., Zhao, M., Tian, Q. And Zhang, W. (2011) Identification of Drought-Responsive microRNAs in Medicago truncatula by Genomewide High-Throughput Sequencing. BMC Genomics, 12, 367. http://www.ncbi.nlm.nih.gov/pmc/articles/PMC3160423/pdf/1471-2164-12-367.pdf

[51] Liu, D., Song, Y., Chen, Z. and Yu, D. (2009) Ectopic Expression of miR396 Suppresses GRF Target Gene Expression and Alters Leaf Growth in Arabidopsis. Physiologia Plantrum, 136, 223-236. http://onlinelibrary.wiley.com/doi/10.1111/j.1399-054.2009.01229.x/epdf http://dx.doi.org/10.1111/j.1399-3054.2009.01229.x

[52] Wang, L., Gu, X., Xu, D., Wang, W., Wang, H., Zeng, M., Chang, Z., Huang, H. and Cui, X. (2011) miR396-Targeted AtGRF Transcription Factors Are Required for Coordination of Cell Division and Differentiation during Leaf Development in Arabidopsis. Journal of Experimental Botany, 62, 761-773. http://www.ncbi.nlm.nih.gov/pmc/articles/PMC3003814/pdf/erq307.pdf http://dx.doi.org/10.1093/jxb/erq307

[53] Yang, F. and Yu, D. (2009) Overexpression of Arabidopsis miR396 Enhances Drought Tolerance in Transgenic Tobacco Plants. Acta Botanica Yunnanica, 31, 421-426.

http://eng.med.wanfangdata.com.cn/PaperDetail.aspx?qkid=ynzwyj\&qcode=ynzwyj200905006 http://dx.doi.org/10.3724/SP.J.1143.2009.09044

[54] Trindade, I., Capitao, C., Dalmay, T., Fevereiro, M.P. and Santos, D.M. (2010) miR398 and miR408 Are Up-Regulated in Response to Water Deficit in Medicago truncatula. Planta, 231, 705-716.

http://link.springer.com/article/10.1007\%2Fs00425-009-1078-0 http://dx.doi.org/10.1007/s00425-009-1078-0

[55] Kantar, M., Unver, T. and Budak, H. (2010) Regulation of Barley miRNAs upon Dehydration Stress Correlated with Target Gene Expression. Functional and Integrative Genomics, 10, 493-507. http://link.springer.com/article/10.1007\%2Fs10142-010-0181-4 http://dx.doi.org/10.1007/s10142-010-0181-4

[56] Boualem, A., Laporte, P., Jovanovic, M., Laffont, C., Plet, J., Combier, J.P., Niebel, A., Crespi, M. and Frugier, F. (2008) MicroRNA166 Controls Root and Nodule Development in Medicago truncatula. The Plant Journal, 54, 876887. http://onlinelibrary.wiley.com/doi/10.1111/j.1365-313X.2008.03448.x/epdf http://dx.doi.org/10.1111/j.1365-313X.2008.03448.x

[57] Malamy, J.E. (2005) Intrinsic and Environmental Response Pathways That Regulate Root System Architecture. Plant, Cell and Environment, 28, 67-77. http://onlinelibrary.wiley.com/doi/10.1111/j.1365-3040.2005.01306.x/epdf http://dx.doi.org/10.1111/j.1365-3040.2005.01306.x

[58] Shukla, L.I., Chinnusamy, V. and Sunkar, R. (2008) The Role of microRNA and Other Endogenous Small RNA in Plant Stress Response. Biochemical et Biophysica Acta, 1779, 743-748.

http://www.researchgate.net/publication/5394672_The_role_of_microRNAs_and_other_endogenous_small_RNAs_in plant stress responses http://dx.doi.org/10.1016/j.bbagrm.2008.04.004

[59] Jiang, M. and Zhang, J. (2001) Effect of Abscisic Acid on Active Oxygen Species, Antioxidative Defence System and Oxidative Damage in Leaves of Maize Seedlings. Plant Cell Physiology, 42, 1265-1273. http://pcp.oxfordjournals.org/content/42/11/1265.full.pdf + html http://dx.doi.org/10.1093/pcp/pce162

[60] Peltzer, D., Dreyer, E. and Polle, A. (2002) Differential Temperature Dependencies of Antioxidative Enzymes in Two Contrasting Species: Fagus sylvatica and Coleus blumei. Plant Physiology and Biochemistry, 40, 141-150. http://www.sciencedirect.com/science/article/pii/S0981942801013523 
http://dx.doi.org/10.1016/S0981-9428(01)01352-3

[61] Loggini, B., Scartazza, A., Brugnoli, E. and Navari-Izzo, F. (1999) Antioxidant Defense System, Pigment Composition, and Photosynthetic Efficiency in Two Wheat Cultivars Subjected to Drought. Plant Physiology, 119, 1091-1099. http://www.plantphysiol.org/content/119/3/1091.full.pdf http://dx.doi.org/10.1104/pp.119.3.1091

[62] Mittler, R. (2002) Oxidative Stress, Antioxidants and Stress Tolerance. Trends in Plant Science, 7, 405-410. http://www.sciencedirect.com/science/article/pii/S1360138502023129 http://dx.doi.org/10.1016/S1360-1385(02)02312-9

[63] Cai, X., Davis, E.J., Ballif, J., Liang, M., Bushman, E., Haroldsen, V., Torabinejad, J. and Wu, Y. (2006) Mutant Identification and Characterization of the Laccase Gene Family in Arabidopsis. Journal of Experimental Botany, 57, 25632569. http://jxb.oxfordjournals.org/content/57/11/2563.long http://dx.doi.org/10.1093/jxb/er1022

[64] Sunkar, R. and Zhu, J.K. (2004) Novel and Stress-Regulated microRNAs and Other Small RNAs from Arabidopsis. The Plant Cell, 16, 2001-2019. http://www.ncbi.nlm.nih.gov/pmc/articles/PMC519194/pdf/tpc1602001.pdf http://dx.doi.org/10.1105/tpc.104.022830

[65] Zhao, B., Liang, R., Ge, L., Li, W., Xiao, H., Lin, H., Ruan, K. and Jin, Y. (2007) Identification of Drought-Induced microRNAs in Rice. Biochemical and Biophysical Research Communications, 354, 585-590.

http://www.sciencedirect.com/science/article/pii/S0006291X07000666 http://dx.doi.org/10.1016/j.bbrc.2007.01.022

[66] Nanjo, T., Kobayashi, M., Yoshiba, Y., Sanada, Y., Wada, K., Tsukaya, H., Kakubari, Y., Yamaguchi Shinozaki, K. and Shinozaki, K.(1999) Biological Functions of Proline in Morphogenesis and Osmotolerance Revealed in Antisense Transgenic Arabidopsis thaliana. The Plant Journal, 18, 185-193.

http://www.sciencedirect.com/science/article/pii/S0981942801013523 http://dx.doi.org/10.1046/j.1365-313X.1999.00438.x

[67] Reddy, A.R., Chaitanya, K.V. and Vivekanandan, M. (2004) Drought Induced Responses of Photosynthesis and Antioxidant Metabolism in Higher Plants. Journal of Plant Physiology, 161, 1189-1202. http://download.bioon.com.cn/upload/month_0909/20090901_5a23deb987c28f13027fA3vfgdivzRaM.attach.pdf http://dx.doi.org/10.1016/j.jplph.2004.01.013

[68] Kantar, M., Lucas, S.J. and Budak, H. (2011) miRNA Expression Patterns of Triticum dicoccoides in Response to Shock Drought Stress. Planta, 233, 471-484. http://link.springer.com/article/10.1007\%2Fs00425-010-1309-4 http://dx.doi.org/10.1007/s00425-010-1309-4

[69] Barrera-Figueroa, B.E., Gao, L., Diop, NN., Wu, Z.G., Ehlers, J.D., Roberts, P.A., Close, TJ., Zhu, J.K. and Liu, R. (2011) Identification and Comparative Analysis of Drought-Associated microRNAs in Two Cowpea Genotypes. BMC Plant Biology, 11, 127. http://www.ncbi.nlm.nih.gov/pmc/articles/PMC3182138/pdf/1471-2229-11-127.pdf http://dx.doi.org/10.1186/1471-2229-11-127

[70] Mangrauthia, S.K., Agarwal, S., Sailaja, B., Madhav, M.S. and Voleti, S.R. (2013) MicroRNAs and Their Role in Salt Stress Response in Plants. In: Ahmad, P., Azooz, M.M. and Prasad, M.N.V., Eds., Salt Stress in Plants: Signalling, Omics and Adaptations, Springer Science, New York, 15-46.

http://www.researchgate.net/publication/278700867_Salt_Stress_in_Plants

[71] Navarro, L., Dunoyer, P. and Jay, F. (2006) A Plant miRNA Contributes to Antibacterial Resistance by Repressing Auxin Signaling. Science, 312, 436-439. http://www.sciencemag.org/content/312/5772/436.full.pdf http://dx.doi.org/10.1126/science.1126088

[72] Sunkar, R., Li, Y.F. and Jagadeeswaran, G. (2012) Functions of microRNAs in Plant Stress Responses. Trends Plant Science, 17, 196-203. http://www.sciencedirect.com/science/article/pii/S136013851200026X http://dx.doi.org/10.1016/j.tplants.2012.01.010

[73] Jones-Rhoades, M.W. and Bartel, D.P. (2004) Computational Identification of Plant microRNAs and Their Targets, Including a Stress-Induced miRNA. Molecular Cell, 14, 787-799. http://www.ncbi.nlm.nih.gov/pubmed/15200956 http://dx.doi.org/10.1016/j.molcel.2004.05.027

[74] Fang, Q., Xu, Z. and Song, R. (2006) Cloning, Characterization and Genetic Engineering of FLC Homolog in Thellungiella halophila. Biochemical and Biophysical Research Communications, 347, 707-714. http://www.sciencedirect.com/science/article/pii/S0006291X0601463X http://dx.doi.org/10.1016/j.bbrc.2006.06.165

[75] Xu, D.Q., Huang, J. and Guo, S.Q. (2008) Overexpression of a TFIIIA-Type Zinc Finger Protein Gene ZFP252 Enhances Drought and Salt Tolerance in Rice (Oryza sativa L.). FEBS Letters, 582, 1037-1043. http://www.sciencedirect.com/science/article/pii/S0014579308001671 http://dx.doi.org/10.1016/j.febslet.2008.02.052 
[76] Cheng, Y. and Long, M. (2007) A Cytosolic NADP-Malic Enzyme Gene from Rice (Oryza sativa L.) Confers Salt Tolerance in Transgenic Arabidopsis. Biotechnology Letters, 29, 1129-1134. http://link.springer.com/article/10.1007\%2Fs10529-007-9347-0 http://dx.doi.org/10.1007/s10529-007-9347-0

[77] Yan, S., Tang, Z., Su, W. and Sun, W. (2005) Proteomic Analysis of Salt Stress-Responsive Proteins in Rice Root. Proteomics, 5, 235-244. http://onlinelibrary.wiley.com/doi/10.1002/pmic.200400853/epdf http://dx.doi.org/10.1002/pmic.200400853

[78] Gao, P., Bai, X., Yang, L., Lv, D., Li, Y., Cai, H., Ji, W., Guo, D. and Zhu, Y. (2010) Over-Expression of osaMIR396c Decreases Salt and Alkali Stress Tolerance. Planta, 231, 991-1001.

http://link.springer.com/article/10.1007\%2Fs00425-010-1104-2 http://dx.doi.org/10.1007/s00425-010-1104-2

[79] Jian, X., Zhang, L., Li, G., Zhang, L., Wang, X., Cao, X., Fang, X. and Chen, F. (2010) Identification of Novel Stress-Regulated microRNAs from Oryza sativa L. Genomics, 95, 47-55. http://www.sciencedirect.com/science/article/pii/S0888754309002158 http://dx.doi.org/10.1016/j.ygeno.2009.08.017

[80] Ding, D., Zhang, L., Wang, H., Liu, Z., Zhang, Z. and Zheng, Y. (2009) Differential Expression of miRNAs in Response to Salt Stress in Maize Roots. Annals of Botany, 103, 29-38.

http://www.ncbi.nlm.nih.gov/pmc/articles/PMC2707283/ http://dx.doi.org/10.1093/aob/mcn205

[81] DePaola, D., Cattonaro, F., Pignone, D. and Sonnante, G. (2012) The miRNAome of Globe Artichoke: Conserved and Novel microRNAs and Target Analysis. BMC Genomics, 13, 41. http://www.biomedcentral.com/1471-2164/13/41 http://dx.doi.org/10.1186/1471-2164-13-41

[82] Liang, M., Haroldsen, V., Cai, X. and Wu, Y. (2006) Expression of Autative Laccase Gene, ZmLAC1, in Maize Primary Roots under Stress. Plant, Cell and Environment, 29, 746-753. http://onlinelibrary.wiley.com/doi/10.1111/j.1365-3040.2005.01435.x/epdf http://dx.doi.org/10.1111/j.1365-3040.2005.01435.x

[83] Attia, H., Karray, N., Msilini, N. and Lachaâl, M. (2011) Effect of Salt Stress on Gene Expression of Superoxide Dismutases and Copper Chaperone in Arabidopsis thaliana. Biologia Plantarum, 55, 159-163.

http://link.springer.com/article/10.1007\%2Fs10535-011-0022-X http://dx.doi.org/10.1007/s10535-011-0022-x

[84] Sunkar, R., Kapoor, A. and Zhu, J.K. (2006) Posttranscriptional Induction of Two Cu/Zn Superoxide Dismutase Genes in Arabidopsis Is Mediated by Downregulation of miR398 and Important for Oxidative Stress Tolerance. Plant Cell, 18, 2051-2065. http://www.ncbi.nlm.nih.gov/pmc/articles/PMC1533975/pdf/tpc1802051.pdf http://dx.doi.org/10.1105/tpc.106.041673

[85] Wei, J.Z., Tirajoh, A., Effendy, J. and Plant, A.L. (2000) Characterization of Salt-Induced Changes in Gene Expression in Tomato ( Lycopersicon esculentum ) Roots and the Role Played by Abscisic Acid. Plant Science, 159, 135-148. http://www.sciencedirect.com/science/article/pii/S0168945200003447 http://dx.doi.org/10.1016/s0168-9452(00)00344-7

[86] Vazquez, F., Gasciolli, V., Crete, P. and Vaucheret, H. (2004) The Nuclear dsRNA Binding Protein HYL1 Is Required for microRNA Accumulation and Plant Development, but Not Posttranscriptional Transgene Silencing. Current Biology, 14, 346-351.

http://ac.els-cdn.com/S0960982204000478/1-s2.0-S0960982204000478-main.pdf?.tid=8eaf430c-20b1-11e5-9a11-000 00aacb35f\&acdnat $=1435838448 \quad 00364940609663 \mathrm{c} 1506 \mathrm{c} 6 \mathrm{fd} 27774 \mathrm{ef} 25$ http://dx.doi.org/10.1016/j.cub.2004.01.035

[87] Schwab, R., Palatnik, J.F., Riester, M., Schommer, C., Schmid, M. and Weigel, D. (2005) Specific Effect of microRNA on the Plant Transcriptome. Developmental Cell, 8, 517-527. http://www.sciencedirect.com/science/article/pii/S1534580705000225 http://dx.doi.org/10.1016/j.devcel.2005.01.018

[88] Wu, M.F., Tian, Q. and Reed, J.W. (2006) Arabidopsis microRNA167 Controls Patterns of ARF6 and ARF8 Expression, and Regulates both Female and Male Reproduction. Development, 133, 4211-4218. http://dev.biologists.org/content/133/21/4211.full.pdf + html http://dx.doi.org/10.1242/dev.02602

[89] Mallory, A.C. and Vaucheret, H. (2006) Functions of microRNAs and Related Small RNAs in Plants. Nature Genetics, 38, S31-S36. http://www.nature.com/ng/journal/v38/n6s/full/ng1791.html http://dx.doi.org/10.1038/ng1791

[90] Jung, H.J. and Kang, H. (2007) Expression and Functional Analyses of microRNA417 in Arabidopsis thaliana under 
Stress Conditions. Plant Physiology and Biochemistry, 45, 805-811.

http://www.sciencedirect.com/science/article/pii/S0981942807001568

http://dx.doi.org/10.1016/j.plaphy.2007.07.015

[91] Xie, Z., Kasschau, K.D. and Carrington, J.C. (2003) Negative Feedback Regulation of Dicer-Like1 in Arabidopsis by microRNA-Guided mRNA Degradation. Current Biology, 13, 784-789.

http://www.sciencedirect.com/science/article/pii/S0960982203002811

http://dx.doi.org/10.1016/s0960-9822(03)00281-1

[92] Ulmasov, T., Hagen, G. and Guilfoyle, T.J. (1997) ARF1, a Transcription Factor That Binds to Auxin Response Elements. Science, 276, 1865-1868. http://www.sciencemag.org/content/276/5320/1865.long http://dx.doi.org/10.1126/science.276.5320.1865

[93] Juarez, M.T., Kui, J.S., Thomas, J., Heller, B.A. and Timmermans, H.C. (2004) MicroRNA-Mediated Repression of Rolled Leaf1 Specific Maize Leaf Polarity. Nature, 42, 84-88.

http://www.nature.com/nature/journal/v428/n6978/full/nature02363.html http://dx.doi.org/10.1038/nature02363

[94] Li, H., Dong, Y., Yin, H., Wang, N., Yang, J., Liu, X., Wang, Y., Wu, J. and Li, X. (2011) Characterization of the Stress Associated microRNAs in Glycine max by Deep Sequencing. BMC Plant Biology, 11, 170. http://www.ncbi.nlm.nih.gov/pmc/articles/PMC3267681/pdf/1471-2229-11-170.pdf http://dx.doi.org/10.1186/1471-2229-11-170

[95] Lu, S.F., Sun, Y.H. and Chiang, V.L. (2008) Stress-Responsive microRNAs in Populus. The Plant Journal, 55, 131151. http://onlinelibrary.wiley.com/doi/10.1111/j.1365-313X.2008.03497.x/pdf http://dx.doi.org/10.1111/j.1365-313X.2008.03497.x 


\author{
Abbreviations \\ miR: MicroRNA \\ siRNA: Small interfering RNAs \\ dsRNA: Double stranded RNA \\ RISC: RNA induced silencing complex \\ Pri-miRNA: Primary miRNA \\ RdRp: RNA dependent RNA polymerase \\ DCL1: Dicer like Protein 1 \\ HYL1: Hyponastic Leaves1 \\ AGO: Argonaute1 \\ ABF: ABA binding factor \\ ZFP: Zinc finger protein \\ ERF: Ethylene responsive factors \\ bZIP: Basic leucine zipper \\ HD-Zip: Homeodomain leucine zipper \\ DREB: DRE-binding protein \\ PLD: Phospholipase D \\ ARFs: Auxin response factors \\ TIR1: Transport inhibitor response 1 \\ GRFs: Growth regulating factors \\ HD-ZIP: Homeodomain-leucine Zipper \\ ROS: Reactive oxygen species \\ $\mathrm{O}_{2}$ : Superoxide radicals \\ $\mathrm{H}_{2} \mathrm{O}_{2}$ : Hydrogen peroxidase \\ $\mathrm{OH}$ : Hydroxyl radicals \\ SOD: Superoxide dismutase \\ CSD: $\mathrm{Cu} / \mathrm{Zn}$-superoxide dismutase \\ CAT: Catalase \\ POD: Peroxidase \\ APX: Ascorbate peroxidase \\ PDH: Proline dehydrogenase \\ TIR: Transport inhibitor response \\ NADP-ME: NADP dependent mallic enzyme \\ HSP: Heat shock protein \\ SNF: Sucrose non-fermenting protein \\ FAD: Flavin adenine dinucleotide \\ TBP: TATA binding protein
}

